\title{
Analysis of Factors Influencing Work Stress on the Health Service Rapid Action Team during the Covid-19 Pandemic in Barru Regency
}

\author{
Andi Sunarti $^{1}$, H. Jalil Genisa ${ }^{2}$, Yusuf ${ }^{3}$ \\ ${ }^{1,2.3}$ Department of Magister Public Health, Sekolah Tinggi Ilmu Kesehatan Tamalatea Makassar, Makassar, \\ Indonesia
}

Corresponding Author: Andi Sunarti

\begin{abstract}
Work stress is the pressure of the mind of work that is felt when the demands faced exceed the strength contained in the worker. During the current COVID-19 pandemic, the workload of health workers has become very high compared to normal conditions; the ongoing emergency caused by Covid-19 has put health services under strong pressure. This study aims to determine the factors that cause work stress in the Barru District Health Office's fast-moving team.
\end{abstract}

The research method used is quantitative with an analytical approach to cross-sectional study design, with a total sample of 65 people from the Covid-19 rapid response team taken by total sampling, used univariate and bivariate analysis using test Chi square.

The results of the study found that there was something that affected work stress, namely the workload of the health department's fast-moving team during the COVID-19 pandemic handling Covid-19 $(p=0.010)$. While other variables did not affect work stress, namely the effect of work $(p=0.000)$, the influence of interpersonal relationships $(p=0.010)$, and the effect of work professionalism $(\mathrm{p}=0.000)$ on the health service rapid movement team during the pandemic-19.

The conclusion of this study is that there are those that affect work stress, namely the workload of the fast-moving team handling Covid-19, while the variables that do not affect work stress are the influence of work, the influence of interpersonal relationships, and the influence of work professionalism, on the fastmoving team handling Covid-19 It is recommended that the Barru District Health
Office harmonize the work atmosphere at the Barru District Health Office, through activities in outdoor and outbound order to be able to maintain group and interpersonal relationships, and make rules that bind the fast-moving team to deal with Covid-19, especially the office. Barru Regency's health is related to additional tasks under certain conditions so that the leadership gives sanctions to the fast-moving team who do not work professionally in dealing with the covid-19 outbreak.

Keywords: Work stress, and the Covid-19 Handling Team

\section{BACKGROUND}

Competition and demands for professionalism are increasingly high, causing a lot of pressures that must be faced by individuals in the work environment. The very detrimental impact of anxiety and stress disorders that are often experienced by the community and employees / workers, especially during the Covid-19 pandemic.

Cartwright and Cooper (2014) argue that work stress is the pressure of the mind of work as a tension or pressure that is felt when the demands faced exceed the strength contained in us. ${ }^{[1]}$

Since late December 2019, the world has faced an outbreak of Covid-19, a new pneumonia caused by the coronavirus disease. This disease was first reported in China, in Wuhan City, in Hubei province (Wang et al., 2020) and is caused by a virus named Coronavirus 2 (SARS-CoV-2). 
The global spread of Covid-19 was declared a pandemic, in March 2020, by the World Health Organization (Huang et al., 2020), in the world today until January 2021 there were 109 million cases of covid-19, 2.42 million of them died. (covid19.co.id). [3]

The impact caused by the Covid-19 pandemic based on research results in China is showing symptoms of post-traumatic stress, in his research it also shows that people experience symptoms of stress $(8.1 \%)$, anxiety $(28.8 \%)$ and moderate to severe depression $(16.5 \%)$.

In Indonesia alone, there have been 14,518 new cases of COVID-19 and there have been more than 1.22 million cases of Covid-19 as of February 14, 2021, and caused 33,367 cases of deaths.

In dealing with the COVID-19 pandemic, health workers are at the forefront of handling it, such as nurses, doctors, administrative staff, and other officers, where health workers also face enormous challenges to their mental health. As is the case in Italy, doctors and nurses have been working more than 100 hours per week. Many doctors and nurses are contaminated, but the exact prevalence of Covid-19 among health workers is difficult to determine because the disease does not often appear in people under 35 years of age.

The impact caused by this pandemic is not only felt by the community or sufferers but also health workers, where stigma and discrimination received by health workers in Indonesia are still common and reported.

South Sulawesi is one of the highest areas of Covid-19 cases outside Java, where there are 33,931 reported cases of Covid-19 and Barru Regency is also one of the districts affected by Covid-19, where there have been closures of 4 (four health centers) caused by 69 health workers being infected with COVID-19 with a total of 137 cases, including Ralla Health Center and Lisu Health Center in Tenete Riaja District, Pekkae Health Center in Tanete Rilau
District, and Palakka Health Center in Barru District.

During the current COVID-19 pandemic, the workload of health workers has become very high compared to normal conditions, the ongoing emergency caused by Covid-19 has put health services under strong pressure. When health workers are faced with a work environment with high job demands and low resources, higher job stress and greater physical and psychological stress symptoms can affect health and social conditions and relationships with families ${ }^{[6]}$.

The results of field observations conducted in Barru Regency that health workers are greatly affected by the current epidemic conditions, where the workload of workers is increasing due to limited human resources and longer working hours than usual, given the increasing number of Covid-19 cases and activities The increasing number of tasks is suspected to be a trigger for stress to health workers.

The Barru District Health Office together with hospitals and health centers are government agencies that are considered to be the spearheads in handling the Covid19 pandemic, where currently the Barru District Health Office has very limited resources in handling Covid-19, namely 65 people who are involved as the Covid-rapid response team19, which consists of; S3 education level is 1, Master is 15 people, $\mathrm{S} 1$ is 35 people, Diploma is 7 people, SMA/equivalent is 7 people.

Sources of stress experienced management team fast motionCovid-19 during a pandemiccovid-19 very closely denganbeban given work, the working time increasingly erratic, and relationships with colleagues in completing the tasks assigned, and professionalism in the work.

Based on the explanation above, the authors are interested in conducting research on "Analysis of Factors Influencing Work Stress on the Health Service Rapid Action Team during the Covid-19 Pandemic in Barru Regency" 


\section{METHOD}

This research is a quantitative study, with an analytical approach, namely research used to answer the influence of the independent variable and the dependent variable, the research design used is a cross sectional study, namely a research design in which the researcher collects data from many different individuals at one point in time.

\section{RESULT}

\section{Univariate Analysis}

Based on age group, from 65 respondents, most of the respondents are 3140 years old, which is $49.7 \%$, then age $<30$ years old is $23.1 \%$ and the lowest is in the $>40$ year age group, which is $27.2 \%$.
Based on gender, from 65 respondents, $53.8 \%$ of respondents were male and $46.2 \%$ were female.

Based on the level of education that, of the 65 respondents, the most with an undergraduate education level, namely $78.5 \%$ of respondents and the lowest with a high school education level, which is $3.1 \%$.

Table 1 Distribution of respondents by characteristic of the Covid-19 rapid response team at the District Health Office. Barru

\begin{tabular}{|l|l|l|}
\hline Bge & Total & Percent \\
\hline$\leq 30$ years & 15 & 23.1 \\
\hline 31-40 years & 32 & 49.2 \\
\hline$>40$ years & 18 & 27.2 \\
\hline Gender & & \\
\hline Male & 35 & 53.8 \\
\hline Female & 30 & 46.2 \\
\hline Education level & & \\
\hline SMA & 2 & 3.1 \\
\hline D3 & 8 & 12.3 \\
\hline S1 & 51 & 78.5 \\
\hline Masters Source: primary data 2021 & 6.2 \\
\hline
\end{tabular}

\section{Bivariate Analysis}

Table 2 Relationship between independent variable and dependent

\begin{tabular}{|c|c|c|c|c|c|c|}
\hline \multirow[t]{3}{*}{ variable Independent variable } & \multicolumn{5}{|c|}{ Stress level } & \multirow[t]{3}{*}{$\mathbf{p}$} \\
\hline & \multicolumn{2}{|c|}{ Mild } & \multicolumn{2}{|c|}{ Heavy } & \multirow{2}{*}{$\begin{array}{l}\text { Total } \\
\mathbf{n}\end{array}$} & \\
\hline & $\mathbf{n}$ & $\%$ & $\mathbf{n}$ & $\%$ & & \\
\hline \multicolumn{6}{|l|}{ Workload } & 0.000 \\
\hline Light & 26 & 81.2 & 6 & 18.8 & 32 & \\
\hline Heavy & 8 & 24.2 & 25 & 75.8 & 33 & \\
\hline \multicolumn{6}{|l|}{ Working Time } & 0.933 \\
\hline Light & 15 & 51.7 & 14 & 48.3 & 29 & \\
\hline Heavy & 19 & 52.8 & 17 & 47.2 & 36 & \\
\hline \multicolumn{6}{|l|}{ Interpersonal Relations } & 0.010 \\
\hline Good & 24 & 66.7 & 12 & 33.3 & 36 & \\
\hline Less & 10 & 34.5 & 19 & 65.5 & 29 & \\
\hline \multicolumn{6}{|l|}{ Professionalism } & 0.571 \\
\hline Enough & 13 & 48.1 & 14 & 51.9 & 27 & \\
\hline Less & 21 & 55.3 & 17 & 44.7 & 38 & \\
\hline
\end{tabular}

Based on workload, it shows that there are 32 respondents who have a light workload category, where $81.2 \%$ of them do not experience stress and there are $18.8 \%$ who experience heavy work stress. Of the 33 respondents who have a heavy workload, there are $24.2 \%$ who have a mild level of stress and $75.8 \%$ who experience a severe category of stress. The results of statistical tests using Chi-square show that the value of $p=0.000$, where this value is smaller than $=0.05$ which means that Ha is accepted and it is concluded that there is an influence or workload is one of the factors causing stress in the fast-moving team handling Covid-19, Barru District Health Office.

Based on time, it shows that there are 29 respondents who have a light working time category, where $51.7 \%$ of them do not experience stress and there are $48.3 \%$ who experience heavy work stress. Of the 36 respondents who had a heavy category of working time, there were $52.8 \%$ who had a mild category of stress and $47.2 \%$ who experienced severe stress. The results of the statistical test using Chisquare show that the value $p=0.933$, where this value is greater than $=0.05$ which means that $\mathrm{Ha}$ is rejected and it is concluded 
that there is no influence or working time is not the cause of stress in the Covid-19 response team. 19 Barru District Health Office.

Based on interpersonal relationships, it shows that there are 36 respondents who have good interpersonal relationships, where $66.6 \%$ of them are in the light stress category and $33.3 \%$ are in the heavy work stress category. Of the 29 respondents who had poor interpersonal relationships, 34.5\% had mild stress levels and $65.5 \%$ experienced severe stress. The results of statistical tests using Chi-square show that the value of $p=0.010$, where this value is smaller than $=0.05$, which means that $\mathrm{Ha}$ is accepted and it is concluded that there is an influence of interpersonal relationships as a cause of stress in the fast-moving team for handling Covid-19 services Barru District Health.

Based on work professionalism, it shows that there are 27 respondents who have sufficient work professionalism, where $48.1 \%$ of them are in the mild stress category and there are $51.9 \%$ who experience heavy work stress. Of the 38 respondents who had work professionalism in the poor category, there were $55.3 \%$ who had mild stress levels and $44.7 \%$ experienced severe stress categories. The results of statistical tests using Chi-square show that the value of $p=0.571$, where this value is greater than $=0.05$, which means that $\mathrm{Ha}$ is rejected and it is concluded that there is no influence or work professionalism is not the cause of stress in the Barru district health rapid movement team

\section{Multivariate analysis}

Table 3 multivariate analysis of stress levels in the Covid-19 rapid response team at the Barru District Health Office. Multivariate Analysis

\begin{tabular}{|l|l|l|l|l|l|}
\hline \multicolumn{1}{|c|}{ Multivariate Analysis } & Sig. & $\operatorname{Exp}(B)$ & $\begin{array}{l}\text { 95.0\% } \\
\text { EXP(B) }\end{array}$ \\
\cline { 3 - 6 } & & & & Cower & Upper \\
\hline \multirow{3}{*}{$\begin{array}{l}\text { Step } \\
1^{\text {a }}\end{array}$} & Workload(1) & .000 & .077 & .022 & .267 \\
\cline { 3 - 6 } & $\begin{array}{l}\text { Interpersonal } \\
\text { Hub(1) }\end{array}$ & .047 & .284 & .082 & 0.985 \\
\cline { 2 - 6 } & Constant & .002 & 6.132 & & \\
\hline
\end{tabular}

The table above in table 4.13 shows that the significance value for the workload variable is 0.000 and the interpersonal relationship is 0.047 . In addition, interpersonal relationships are the most dominant variable causing stress in the Covid-rapid response team handling19 the Barru District Health Office with an Exp (B) value or a large risk of 0.284 or the Covid-19 fast-moving team that has poor interpersonal relationships. 0.284 times chance of experiencing work stress.

\section{DISCUSSION}

Covid-19 has plagued the entire world, where it has spread so rapidly and has caused such a huge impact on all aspects of people's lives globally. The impact that is most felt is the pressure of life not only on the general public, but also on the employment sector. Covid-19, which worsens and causes chaos, is not only physically damaging, but also psychologically damaging such as stress. In this study, it was found that the stress level of the Covid-19 rapid response team at the Barru Regency health office was generally in the severe category, this condition if left unchecked will have an impact both directly and indirectly.

The direct impact is felt by the workers themselves, where more work will be neglected, work buildup, reduced work motivation, slack morale, high absenteeism levels and of course a direct impact on the quality of services available at the Barru District Health Office.

Another impact of this condition is that more and more health programs that should be completed this year will be increasingly neglected, because currently the government has allocated most of the funds for other health programs to the handling of COVID-19 throughout Indonesia, especially the Barru district.

Interventions in existing health programs in Barru Regency such as diarrhea, TB, DHF, and other diseases will experience a significant spike in cases if they do not get proper attention or 
treatment, and will have an external impact on the quality or degree of public health in Barru Regency.

In this study it was found that excessive workload and interpersonal relationships are the causes of work stress which will be described as follows:

\section{Workload}

Excessive workload on workers is almost felt by all the fast-moving teams handling Covid-19 of the Barru district health office, feelings Tired and tired and bored in dealing with work during the current covid-19 pandemic, excessive workload on workers causes workers to become depressed and excessive anxiety in workers ${ }^{[7}$

The tasks given during the pandemic also vary from field officers to workers in the field, with administrative duties, fieldwork is a challenge faced by the health service officers of the Barru Regency, where they have to carry out supervision, monitor the process of tracing case findings to efforts to prevent Covid-19.

The increasing number of Covid-19 cases in Barru Regency is not compared to the number of Covid-19 rapid response teams in Barru Regency, where currently there are 65 Covid-19 rapid response teams where only productive groups are given additional tasks. This condition further complicates the situation because the reduced number of rapid response teams for handling Covid-19 coupled with an increasing workload, not to mention the main tasks that must be completed.

The number of additional tasks given to the Covid-19 rapid response team made the stress level increase, as in this study it was found that excessive workload was one of the factors causing work stress in the Covid-19 rapid response team at the Barru District Health Office. This study is also in line with that conducted by Yuanyuan Mo MM et al. 2020 revealed that the total stress burden of nurses helping to deal with COVID-19 is very large, the pressure that health workers get during the current covid-19 pandemic poses a considerable challenge because it greatly affects the officers and families psychologically. ${ }^{[8}$

The workload on nurses in this study is still very low, because they have fear, where all nurses have a high enough level of concern about the work being carried out during the Covid-19 pandemic. Support from health workers, especially from the workplace and family environment, is needed by health workers.

\section{Working hours}

During the current pandemic, it creates chaos in terms of time management, where workers or fast-moving teams for handling Covid-19 no longer work normally, especially for health workers.

The excessive working time of health workers is due to the acceleration of the covid-19 prevention and control program that must be accelerated, the covid19 vaccine socialization program is also a challenge for health workers at the new district health office, because not all people want to accept this program, because the existence of hoax information circulating related to the impact after taking the vaccine, some were paralyzed, some even died from the vaccine, this information is the duty of health workers to educate the public. This causes this condition to be more difficult to overcome quickly.

There are also many health workers in the Barru Regency Health Office who are categorized as high risk or elderly, to work from home, so they have work time that tends to be vacant and have time to rest at home, so in this study there was no correlation or effect of working time with stress, work on the fast-moving team for handling Covid-19, the Barru District Health Office.

The working time of the Covid-19 fast-moving team has been regulated by the leadership so that during this pandemic, some have excess working time, some don't, depending on the condition and age of the Covid-19 rapid-moving team, for those who 
have symptoms it is advisable to get checked out and do self-isolation before the results come out.

After this vaccination program, working hours have started to return to normal, with various limitations, the Covid19 rapid response team will continue to work as usual, namely being absent at 7.30 and returning home at 16.00 . This condition is certainly a breath of fresh air for others because various work programs that have been delayed can be completed immediately. However, there is also a fastmoving team for handling Covid-19 who must work outside the set working hours, such as escorting health protocols with the police and soldier.

The most noticeable working time was at the beginning of the pandemic in April 2020, where there was a tightening and implementation of health protocols in markets, cafes, streets, vehicles, places of worship, food stalls and other crowded places.

Working time also plays an important role in increasing one's work productivity, such as the research conducted by Rosyanti 2020, where the longer a person's working time, which is more than 6-8 hours a day, the more potential to make mistakes at work and cause negative things,

During the current pandemic, health workers who ideally work an average of six days a week, have to take their time off Saturday or Sunday because they have to complete the assigned tasks, this condition is considered less effective but still must be done to maintain or prevent the transmission of COVID-19, even more massive.

\section{Interpersonal Relations}

Work stress is strongly influenced by the relationship between the Covid-19 rapid response team, as in this study which revealed the fact that interpersonal relationships are a factor causing work stress in the Covid-rapid response team at the19 Barru District Health Office. This research is in line with research conducted by Robbins 2007.

Interpersonal relations or social environment factors also affect work stress on employees. Where the existence of social support plays a role in encouraging someone in their work, if there are no supportive social environmental factors, the stress level of employees will be high.

Differences in background are often a problem in an institution, be it educational background, degree, place of study, ethnicity or race, in this study it was revealed that differences in educational institutions are still common in the health office of Barru Regency, but This situation is not too prominent, because longare able to unite, although feelings of envy and displeasure with -standing friendships the fast-moving team handling Covid-19 still occur.

The ego of seniority also still occurs in the Barru district health office, where more senior officers are more dominant than junior ones even though their status and duties are the same, but they still get different treatment. This will be increasingly difficult to control because it has been happening for a long time and has been passed down from generation to generation.

This condition then makes interpersonal relationships disharmonious between the Covid-19, moreover there is fast-moving teamthe Covid-19 fast-moving team who is indifferent to the tasks given, this condition makes the situation inside and outside the office disharmonious, other things What is revealed in this study is the poor interpersonal relationship of the Covid19 rapid response team, it is not shown directly, so that we are in an informal meeting or meeting, as if nothing happened, and their relationship is on good terms. course, is different from what has been revealed in this study.

Interpersonal relations between employees are not all bad, there are also many officers who have high social concern for others, such as when an officer or family 
member is sick, they visit each other, if a relative dies they give each other support.

Support from people around is very important in order to minimize the occurrence of work stress on health workers which leads to a decrease in the degree of public health and the spread of the covid-19 outbreak, social support to fellow officers is very supportive in increasing motivation to carry out tasks ${ }^{[11]}$

\section{Work professionalism}

Stress A person's work really depends on a person's ability or condition at work, in the current pandemic conditions the professionalism of the Covid-19 fastmoving team is tested, because there will be several Covid-19 fast-moving teams who are not willing to carry out the additional tasks assigned to them, because assume they are not paid for it.

Work professionalism is not only measured by the presence of instructions or encouragement from other people and even superiors, but also because of the encouragement from oneself. The current pandemic condition, which is completely limited, both facilities and infrastructure including human resources, requires a team to move quickly to handle Covid-19 to be tenacious in covering each other independently.

The Barru Regency Office is currently carrying out internal restrictions so that the number of officers with limited offices, coupled with increased tasks, will further increase stress levels and can cause work productivity to decrease.

Initiatives from the rapid response team for handling Covid-19 in the current situation are urgently needed in providing or easing each other's burdens, teamwork must still be established so that the community remains protected from Covid-19 transmission. The independence of the fastmoving team to handle Covid-19 and the culture of mutual cooperation that has existed for a long time at the Barru district health office must be maintained, especially in the midst of the epidemic conditions that are increasingly spreading to remote villages.

Health workers with a poor level of professionalism have a tendency to have less stress, because they are apathetic to what is happening at the moment and stay focused on their main job without mingling with other teams who have been struggling to deal with the current covid-19 pandemic.

The Barru District Health Office has actually made various efforts so that in this pandemic condition, all the rapid response teams for handling Covid-19 make their maximum contribution, because if this condition is allowed to continue, it will have an even greater impact in all aspects of life.

The results of research revealed by Horesh \& Brown, 2020 that work professionalism in terms of independence and tenacity in work will be very helpful in the healing process of trauma that occurs to patients and fellow co-workers, so that the support and motivation and hard work of health workers will greatly help alleviate the burden of society in the midst of the Covid19 outbreak. ${ }^{[12]}$

\section{CONCLUSION}

The variables that affect work stress are the workload and interpersonal relationships of the fast-moving team handling Covid-19, the Barru District Health Office, while the variables of working time and professionalism have no effect on work stress in the fast-moving team handling Covid-19, the Barru District Health Office.

\section{Acknowledgement: None}

\section{Conflict of Interest: None}

Source of Funding: None

Ethical Approval: Approved

\section{REFERENCES}

1. Carry Cooper dan Alison Straw. 2014. Stres Manajemen Sukses Dalam Sepekan. Editor: Fathudin. Jakarta : Kesaint Blanc 
2. Wang, C., Horby, P. W., Hayden, F. G., \& Gao, G. F. (2020). A novel coronavirus outbreak of global health concern. The Lancet, 395(10223), 470-473. https://doi.org/10.1016/S01406736(20)30185-9

3. Huang, C., Wang, Y., Li, X., Ren, L., Zhao, J., Hu, Y., Zhang, L., Fan, G., Xu, J., Gu, X., Cheng, Z., Yu, T., Xia, J., Wei, Y., Wu, W., Xie, X., Yin, W., Li, H., Liu, M., ... Cao, B. (2020). Clinical features of patients infected with 2019 novel coronavirus in Wuhan, China. The Lancet, 395(10223), 497-506. https://doi.org/10.1016/S01406736(20)30183-

4. Sterpetti, A. V. (2020). Lessons Learned During the COVID-19 Virus Pandemic. Journal of the American College of Surgeons, 230(6), 1092-1093. https://doi.org/10.1016/j.jamcollsurg.2020.0 3.018

5. Covid.kemkes.go.id. Status Harian Covid19 di Indonesia. https://Covid19.kemkes.go.id/situasiinfeksi-emerging/info-corona-virus/. Diakses pada 25 April 2020 - 12 Juli 2020

6. Xiang, Y. T., Yang, Y., Li, W., Zhang, L., Zhang, Q., Cheung, T., \& Ng, C. H. (2020). Timely mental health care for the 2019 novel coronavirus outbreak is urgently needed. The Lancet Psychiatry, 7(3), 228$229 . \quad \mathrm{https}: / /$ doi.org/10.1016/S22150366(20)30046-8

7. Sampaio F, Sequeira C, Teixeira L. Impact of COVID-19 outbreak on nurses' mental health: A prospective cohort study. Environ Res. 2021 Mar;194:110620. doi: 10.1016/j.envres.2020.110620. Epub 2020 Dec 11. PMID: 33316228; PMCID: PMC7732227
8. Shan, C., Yao, Y. F., Yang, X. Lou, Zhou, Y. W., Gao, G., Peng, Y., Yang, L., Hu, X., Xiong, J., Jiang, R. Di, Zhang, H. J., Gao, X. X., Peng, C., Min, J., Chen, Y., Si, H. R., Wu, J., Zhou, P., Wang, Y. Y., ... Yuan, Z. M. (2020). Infection with novel coronavirus (SARS-CoV-2) causes pneumonia in Rhesus macaques. Cell Research, 30(8), 670-677. https://doi.org/10.1038/s41422020-0364-z

9. Rosyanti, L., \& Hadi, I. (2020). Dampak Psikologis dalam Memberikan Perawatan dan Layanan Kesehatan Pasien COVID-19 pada Tenaga Profesional Kesehatan. Health Information: Jurnal Penelitian, 12(1), 107130. https://doi.org/10.36990/hijp.vi.191

10. Robbins, S.P., and Judge, T.A. Perilaku Organisasi, Edisi-12, Jakarta: Salemba Empat.2008

11. Jembarawati, O. (2020). Stres dan Dukungan Sosial pada Perawat, Dokter dan Tenaga Kesehatan pada Masa Pandemi Covid-19. PSISULA: Prosiding Berkala Psikologi, 2(November), 292-299.

12. Horesh, D., \& Brown, A. D. (2020). Covid19 response: Traumatic stress in the age of Covid-19: A call to close critical gaps and adapt to new realities. Psychological Trauma: Theory, Research, Practice, and Policy, 12(4), 331-335. https://doi.org/10.1037/TRA0000592

How to cite this article: Sunarti A, H. Jalil Genisa, Yusuf. Analysis of factors influencing work stress on the health service rapid action team during the Covid-19 pandemic in Barru Regency. Gal Int J Health Sci Res. 2021; 6(3): 38-45. DOI: https://doi.org/10.52403/gijhsr. 20210707 